\title{
GOVERNMENT IN THE NORTHWEST TERRITORIES THE CARROTHERS COMMISSION REPORT
}

\author{
D. H. SEARLE*
}

\section{Introduction}

The purpose of this paper is to outline and comment on the recommendations of the Advisory Commission on the Development of Government in The Northwest Territories, as the Commission was formally named, which for the sake of brevity and because of common usage in the N.W.T. shall hereinafter be called the "Carrothers Commission". This commission, by common usage, has been named after the commission chairman, A. W. R. Carrothers, Dean of the Faculty of Law, The University of Western Ontario. In addition to Dean Carrothers, as Chairman, the commission consisted of two other members. These were Mr. Jean Beetz, Professor of the Law, University of Montreal, and John H. Parker, a professional engineer and Mayor of the Town of Yellowknife.

\section{Terms of Reference}

By Order-in-Council 1005, dated 3 June, 1965, the Carrothers Commission was constituted for the purpose of advising the Minister of Indian Affairs and Northern Development on matters relating to the political development of the Northwest Territories. These terms of reference, however, were expanded somewhat by the commission to include economic and social, as well as political development, as a result of the commission's interpretation of the Order-in-Council as having merely given executive effect to a speech by the Minister of Indian Affairs and Northern Development in the House of Commons on 11 May, 1965. This speech, in part, reads as follows:

It has therefore been decided to appoint an Advisory Commission on the Development of Government in the Northwest Territories. The terms of reference of the Commission will enable it to review government in the Northwest Territories and to recommend to the Minister of Northern Affairs and Natural Resources the form of government that seems most appropriate consistent with political, economic and social development. ${ }^{2}$

Through the vehicle of interpretation, therefore, the commission, in effect, expanded its terms of reference. It would appear logical to do this because in order to advise the Minister of Indian Affairs and Northern Development on matters relating to the political development of the Northwest Territories, considerations of economic and social development must be assessed because they bear directly upon how far and how fast self-government may be granted.

\section{History}

In 1963 two Bills, being Bills C-83 and C-84, were referred to the Standing Committee on Mines, Forests and Waters. These were the

- B.A., LL.B. (Alta.).

1 Report of the Advisory Commission on the Development of Government in the Northwest Territories, 1966, Vol. 1, at 2 . 
two now-infamous "division" bills, which between them, if enacted, would have divided the present Northwest Territories into two separate territories, with two separate Councils and two separate bodies of law. Bill C-83 would have become the body of law for the Mackenzie Territory and Bill C-84 would have become the body of law for the Nunnassiaq Territory.

As a result of the evidence before this committee and a recommendation at a subsequent session of the Territorial Council, the Carrothers Commission was constituted on 3 June, 1965 by Order-in-Council 1005. This history is borne out by the Commission's report where, when dealing with the issue of division, the following statement is made:

The question of division was the issue which ultimately led to the appointment of this commission and we should comment on it in some detail.2

\section{Recommendations}

The recommendations made by the Carrothers Commission were a result of travel by the commission of some 10,000 air miles within the N.W.T. Approximately 59 public hearings were held in 51 communities and the commission came in contact with approximately 3,000 adults, being a ratio greater than 1 out of every 5 adult residents of the N.W.T.

Before dealing with the specific recommendations, the commission defined certain postulates which it believed "to be valid for and relevant to the economic, social and political future of the peoples of the Northwest Territories." "These postulates, in the Commission's words "represent a choice of values" or value judgments designed to give direction to the Commission's study. These postulates are as follows:

1. Every citizen of Canada has a claim to participate in the institutions of responsible government under the Canadian constitution; it is a goal of political development of the Northwest Territories that the optimum number of Canadian citizens resident in the Territories should, at an optimum speed, participate in government as fully as Canadian citizens in the provinces."

2. The competence of political institutions should be commensurate with the dimensions of the social and economic problems in the political units. ${ }^{5}$

3. The structure and technique of government should not be foreign to the Canadian political tradition. ${ }^{6}$

4. Every resident of the N.W.T. for whom freedom of movement within and without the Territories is not a realistic fact has a claim to economic opportunity that will provide a standard of living that does not deviate substantially from the Canadian norm. ${ }^{7}$

5. So long as the N.W.T. remains a political unit or units separate from the provinces, the federal government has a major, although not necessarily an exclusive, responsibility for its economic development. ${ }^{8}$ 
6. The Eskimos and Indians, as indigenous minorities, should be free to maintain their cultural and ethnic identities, subject to fundamental human rights as recognized by the Canadian constitution. ${ }^{\circ}$

Looking now at the specific recommendations made by the Commission, the foregoing postulates being used to give some direction, the Commission first recommended that due to the uniqueness and unpredictability of future political development, the question of the government of the N.W.T. should be reviewed again in ten years. In the words of the Commission, "we have sought to make our recommendations appropriate for a decade." 10

The second recommendation deals with Bills C-83 and C-84, the infamous "division" bills. The Commission recommends against division of the N.W.T. into two separate territories at this time. The strongest argument against division which was adopted by the Commission was that division would prejudice the political interests of the indigenous peoples of the N.W.T. as Canadian citizens. The Commission's own words can best explain this argument and are as follows:

With division there would be a very great risk that the eastern Arctic would

become sealed off, would remain dominated by the central government, and might never acquire anything more than a nominal form of self-government.11

What did surprise the Commission was their discovery of what was politely termed a "minority sentiment" for division as a program of political development. This significant finding by the Commission confirmed for most northerners their view that Bills C-83 and C-84 were drafted by the bureaucracy for the bureaucracy with a view neither to democracy nor justice but rather with a view to building civil service empires aimed only at some vague and illusive idea of administrative efficiency. Needless to say this recommendation against division has been well received by the public.

The third recommendation was that the capital of the Northwest Territories should be moved from Ottawa and should be located at Yellowknife, within the Northwest Territories. This recommendation, was made to the Minister on 30 August, 1966. On the 18th day of January, 1967, the Minister of Indian Affairs and Northern Development, at Yellowknife, acted upon this recommendation and named Yellowknife the capital of the Northwest Territories.

The fourth recommendation, and the lengthiest of all recommendations dealt with the structure of the Territorial Government. The Commission recommended that there continue to be a Commissioner of the N.W.T. whose appointment should also continue to be during the pleasure of the Governor-General-in-Council on the recommendation of the Minister of Indian Affairs. One change, however, recommended by the Commission is that such Commissioner would hold the rank of a Deputy Minister and be responsible directly to the Minister, thereby preventing and avoiding a cutting-off of contact between the Minister and the Commissioner by federal officers of the Department of Indian Affairs and Northern Development. In addition, the Commission recommended that

I Id., at 135.

10 Id., at 141. 
the Commissioner have power to dissolve the Legislative Assembly and that he reside within the N.W.T., presumably at the capital. It is contemplated that the role of the Commissioner would, with the passage of time, develop into that of a Lieutenant-Governor.

As part of the fourth recommendation, the commission further recommended that there be a Deputy Commissioner, to be, at the appropriate time, chosen from among the elected members. This office, as it is contemplated, could develop and evolve into that of a provincial premier.

The Commission also recommended that there be an Executive Council to be composed ultimately, though not initially nor necessarily, from elected members of the Legislative Assembly. This body presumably would eventually evolve into a form of cabinet.

Also as part of the fourth recommendation, the Commission further recommended that the present Council of the Northwest Territories be changed, in name, to the Legislative Assembly of the Northwest Territories, with a membership of eighteen persons of which fourteen would be elected and four appointed. This would double the present number of elected representatives which now stand at seven and would roughly allow for one member of the Legislative Assembly for every 2,000 persons resident within the Northwest Territories; not too large a representation considering distances, language barriers and the lack of normal news media within the Northwest Territories.

Regarding appointed members of the proposed Legislative Assembly, the recommendation that there be four in number, rather than the present five, is an acknowledgment of the policy that eventually the Legislative Assembly should be fully elected and a period of five years for this to occur is suggested.

With regard to the voting age, the Commission recommended that this be reduced to nineteen years.

With regard to a Territorial Civil Service, the Carrothers Commission recommended that administrative functions be transferred to the Territorial Civil Service on a specified schedule to take place within the next two years. To date of writing, the only civil servants working in the field for the Territorial Government are the liquor commission and the correction service personnel. This is most important if the directives and dictates of the proposed Legislative Assembly are to be carried out. In the past the Commissioner of the N.W.T. has been compelled to rely upon the federal civil servants of the Department of Northern Affairs who are responsible, not to the Commissioner, but to the Deputy Minister via the Director of the Northern Administrative Branch. Due to being less than the rank of deputy minister, on the one hand, and due to the civil service structure of federal responsibility to the Deputy Minister, on the other hand, the Commissioner of the N.W.T., if he is out of favour with the Deputy Minister, could be cut off from the Minister above and from the federal civil servants below, leaving the Commissioner emasculated to say the least. This, in turn, has had the same effect upon the Territorial Council.

In the area of economic development, the Commission recommended the establishment of a Department of Economic Development and a 
Northwest Territories Development Board together with a Northwest Territories Development Corporation and regional economic planning.

Regarding other departments, the Commission recommended a Department of Local Government, a Department of Education, a Department of Welfare and Social Services, a Department of Public Works, a Department of Justice and a Department of Lands and Resources, all of which would be responsible to the Commissioner and would have their respective functions transferred to them by the federal government. Of importance to the legal profession in the N.W.T. is the recommendation that the Land Titles Office, which incredible as it may seem, is presently in Ottawa, be located in the N.W.T. at the capital.

In concluding, the Carrothers Commission recommended that an agreement be entered into between the federal and territorial governments regarding the transfer ultimately to the territorial government of administrative responsibility for Indians and Eskimos so that welfare and education programs in the N.W.T. as between whites and natives are not dissimilar. It was also suggested that representatives of the territorial government be allowed, as observers, to be present at FederalProvincial and Inter-Provincial Conferences.

\section{Comment}

With regard to the form of government recommended by the Carrothers Commission, the choices open to the Commission were stated as follows:

The choice of constitutional forms for the Northwest Territories appear to be the status quo, full provincial status, some intermediary stage between the status quo and provincial status, and the status of a unitary dependency.12

As to the choice obviously made by the Commission, no better explanation can be given than to use the Commission's own words which are as follows:

In summary, we conclude that what is required now is not provincehood but the means of growth to provincehood; that the best move for the peoples of the Northwest Territories at the present time is to retain the Territories as a political unit, to locate the government of the Territories within the Territories, to decentralize its operations as far as practicable, to transfer administrative functions from the central to the territorial government in order that the latter may be accountable on site for the administration of the public business and to concentrate on economic development and opportunity for the residents of the north. ${ }^{13}$

The intermediary stage between the status quo and provincial status was chosen. Why was this done? The answer may lie in the area of the Commission members' knowledge that to ask for provincial status or anything close to it, would be regarded by the Department of Indian Affairs as revolutionary rather than evolutionary. Coupled with this, is the knowledge that the federal government still regards Canada's north as a colony of the federal government, the natural resources of which colony are destined to be exploited by the federal government not for benefit of residents of the Northwest Territories, but for the benefit of all Canadians. To have suggested provincial status would have required a study and a recommendation regarding the transfer of ownership in the natural resources of the Northwest Territories from the 
federal government to any new Province of the North. However, it can accurately be stated that the federal government does not ever plan to transfer ownership in these resources.

With regard to the ownership of natural resources and their transfer, Professor A. R. Thompson of the Faculty of Law, The University of Alberta, prepared and submitted an excellent brief which was all but ignored by the Carrothers Commission. With regard to Professor Thompson's submissions, the Commission said the following:

These submissions have been considered, but we consider that it would be premature to express an opinion on this question. ${ }^{14}$

In the end, therefore, and assuming that all of the recommendations of the Carrothers Commission are enacted into law (which is not likely), the North would continue at best to be a colony of the federal government with a Commissioner appointed by the Minister of Indian Affairs and responsible to the said Minister, not the legislature. If the evolution recommended by the Carrothers Commission does in fact occur, it can be hoped that it occurs within the next 100 years of Confederation.

The people of the North are unfaltering in their celebration of the Centennial. It is true that the North is part of Canada, but it is not part of Confederation.

14 Id., at 208.

\section{OWNERSHIP OF NATURAL RESOURCES IN THE NORTHWEST TERRITORIES}

\section{A. R. THOMPSON*}

\section{THE HISTORICAL PRECEDENTS}

Development of natural resources is regarded as the key to economic and social development in newly self-governing countries. ${ }^{1}$ It was so regarded by our forefathers when the western provinces of Canada emerged to equality of status with the other Canadian provinces. The story of the political struggle through which these provinces wrested ownership of natural resources from the central government of Canada is a recent chapter in Canadian history-one that is told with authority by Chester Martin in his treatise on "Dominion Lands" Policy." It had its counterpart in the story of the political struggles by the Rocky Mountain states to gain control of mineral resources in the public domain in the United States, leading to the Mineral Leasing Act, $1920 .^{3}$ This Act of Congress continued federal control over mineral resources in the public domain, but it gave the fruits of exploitation to the regions and

* A. R. Thompson, B.A., LL.B. (Man.), LI.M. (Tor.), Professor, Faculty of Law, The University of Alberta. In 1967, Visiting Professor, Faculty of Law, University of Auckland.

1 U.N. Resolution No. 1803 (xvii) of 14 December, 1962, concerning Permanent Sovereignty over Natural Resources.

2 Part II of Volume II of the series Canadian Frontiers of Settlement, MacMillan, 1938. In particular, Chapter XII, entitled "The Natural Resources Question"; The Transfer of 1930, describes the attitudes and events leading to the natural resources transfer agreements of 1930 .

3 See, for example, Robbins, Our Landed Heritage, University of Nebraska Press, Bison Edition, 1962. 